An incidental psychological contribution, which will not fail of catching the attention of those psychologists and sociologists who are dwelling upon the importance of imitation, is found on p. II. Experiments were made upon five different primary rooms in Worcester, Mass., to determine the ' natural' place of beginning in counting off on the finger. In two cases the teacher allowed one child to count while the other children watched. In both cases every other child followed exactly the example of the leader.

It is to be hoped that Dr. Conant, or some other equally competent student, will supplement this book with another, in which the anthropological data concerning the circumstances and motives with relation to which savages count will be collected so as to extend and to justify the philological data and conclusions; and will also take up the matter of systems of measurement, upon both a philological and anthropological basis. In this case the contributions to psychology will be direct and not simply incidental.

University of Chicago.

JoHN DrweY.

Die Spiele der Thiere. KARL Groos. Jena, Gustav Fischer. 1896. Pp. xvi 359 .

When it is learned that the above is a volume of $34^{\circ}$ pages, exclusive of an excellent index, it will at once be plain that the treatmen: of the subject is of the most thorough kind.

The book is well printed on good paper and with a type that encourages one to keep on when once he has begun the reading-a very important matter in a work which is, after all, of special rather than general interest. In the introduction a succinct statement of the author's entire position is given. The work is rendered valuable for reference by reason of a very full bibliography.

The subjects of the different chapters are as follows:

I. Consideration of the theory that play is an expression of excess or overflow of energy.

II. Play and hinct.

III. Forms of Play among Animals, which is continued in a fourth chapter as 'Die Liebesspiele,' the two together making over 200 pages of matter.

V. The Psychology of Animal Play.

The author gives the most ample evidence of familiarity with the literature that bears on his subject, whether directly or indirectly, and well-known American writers on psychology are quoted again and again, some of the citations indicating that the writer appreciates not 
only their matter but their style, as when he says: "James hat vollkommen Recht, wenn er z. B. bei der brütenden Henne keine weiteren Erfahrungen und psychischen Vorgänge annimmt als das gefühl, das eben ein solches $\mathrm{Ei}$, ' the never-to-be-too-much-sat-upon object 'ist."

No doubt Professor Baldwin's work on mental development would have proved to the author a mine to be well worked had it appeared in time. However, it will serve a still better purpose in connection with that second treatise Dr. Groos promises, 'Die Spiele der Menschen.'

Briefly as to the author's views: Animal psychology has been wrongly regarded as a sort of mere amusement in consequence of which the subject has suffered. It has also been lacking in aims and methods. It would be well to consider what in men is animal (thierisch) if we go no further, and this implies a close study of animals. The author then sets forth his views as to the qualifications of the man who would make a thoroughly successful study of animals, and they so perfectly agree with my own that I will quote the passage in the hope that the editor may not throw it out for being too lengthy.

"Der Verfasser einer Psychologie der thierischen Spiele müsste eigentlich nicht nur zwei, sondern mehrere Seelen in seiner Brust beherbergen. Er müsste mit einer allgemeinen psychologischen, physiologischen und biologischen Vorbildung die Erfahrungen eines Weltreisenden, die Kenntnisse eines Thiergarten-Directors und die Erinnerungen eines wahrheitsliebenden Oberförsters vereinigen. Und auch dann würde er schwerlich sein Werk zu einem befriedigenden Abschluss führen können, wenn er nicht zugleich mit den Bestrebungen der modernen Aesthetik vertraut wäre. Ja gerade diesen letzten Punkt halte ich für so wesentlich, dass ich behaupten möchte : nur ein Aesthetiker kann die Psychologie des Spiels schreiben."

Dr. Groos does not reject the 'overflow of energy' theory originating with Schiller and expanded by Spencer, but considers it inadequate.

Play is a development and preparation for the use or expression of certain instincts. Without this preparation the 'blind might' of instinct would often be unavailing.

The author's work is saturated with the doctrines of evolution, of which he makes abundant use and with critical discrimination.

Bearing in mind the all pervading nature of the sexual instinct, he endeavors to prove that play is essential for the successful attainment of the the objects of this instinct, especially on account of the instinctive shyness of the females. 
Dr. Groos thinks he has discovered a new 'principle' as described above, necessary to complete and correct those of Wallace, Weismann, Galton, Spencer and Darwin. He does not believe that the females select the males, but that the peculiar forms and colors of the males tend to diminish the shyness of the female, so that with the addition of his own principle that great end of nature, the propagation of species, is accomplished. Through these two principles, attraction of females by the forms, colors, etc., of males, and that behavior for which play is a preparation, suitable matings result.

The principle of special interest in psychology in this connection, and especially for $A$ sthetics, is 'der Scheinthätigkeit oder der bewussten Selbstäuschung.'

Whether one agrees wholly with the writer of this book or not, he will get many tidbits by the way and is likely to feel more than ever the force of the well-known saying of Bacon, 'Reading maketh a full man.'

Wesley Muls.

Montreni.

\section{THE PSYCHOLOGY OF ART.}

Ueber den psychologischen Ursprung der Poesie und Kunst. M. J. Monrad. Archiv f. system. Philosophie, Bd. I. 347-362. 1895 .

In the fourth chapter of the 'Poetics' Aristotle refers the psychological origin of Poetry to two sources, the impulse to and delight in imitation and the impulse to and delight in rhythm and harmony. Connecting the first with the theoretic impulse-we first learn by imitation-he finds an essential element in æsthetic enjoyment to be the pleasure of recognition. Certain persons in whom the imitative impulse was stronger than the rest began with imitations which expressed the temporary interest of the occasion, and these, perfected by practice, gradually became a developed art.

The essay of Herr Monrad is an elaboration and application to art generally of the above Aristotelian theses respecting the origin and development of poetry. Aristotle's remark about learning beginning with imitation receives a deeper significance than its author probably intended in the observation that in learning there is an inwardizing, a spiritual reproduction, of the object. Such idealization is a characteristic factor in human imitation, and enables it to rise above the brute stage at which it begins and where it approaches the reflex type, 